\title{
The Conceptual and Methodological Construction of a 'Global' Teacher Identity through TALIS
}

\author{
Armend Tahirsylaj ${ }^{* 1}$, William C. Smith ${ }^{2}$, Gulab Khan ${ }^{3}$, AND \\ WIELAND WERMKE ${ }^{4}$
}

$\approx$ The present article investigates the construction of a 'global' teacher identity by the Organisation for Economic Cooperation and Development (OECD) since the introduction of the Teaching and Learning International Survey (TALIS) in 2008. We critically examine TALIS-related conceptual frameworks, survey questionnaires and statistically driven scales of teachers' professional attitudes internationally. A theoretical, education-based framing of didaktik and curriculum pedagogical traditions is used to discuss conceptual bias in TALIS conceptual frameworks as well as the sociologically based idea of TALIS as a pedagogic device used as a technology to gain symbolic power for making the teachers of tomorrow. Methodologically relying on document analysis, we examine TALIS 2008, 2013 and 2018 background documents to highlight the ideologically driven construction of a certain model of effective teachers, and refer to associated TALIS technical reports to examine validity issues in scales that are methodologically and statistically driven in order to increase the robustness of the results. The article identifies biases in the OECD's construction of a 'global' teacher identity that are reflected in TALIS conceptual frameworks and survey questions and statistically justified through associated scales.

Keywords: curriculum theory, didaktik, global teacher identity, pedagogic device, TALIS

1 * Corresponding Author. Department of Teacher Education, Norwegian University of Science and Technology (NTNU), Norway; armend.tahirsylaj@ntnu.no.

2 Moray House School of Education and Sport, University of Edinburgh, UK.

3 School of Education, Lahore University of Management Sciences (LUMS), Pakistan.

4 Department of Special Education, Stockholm University, Sweden. 


\title{
Konceptualno in metodološko oblikovanje "globalne» identitete učitelja s pomočjo TALIS
}

\author{
Armend Tahirsylaj, William C. Smith, Gulab Khan in \\ Wieland WeRMKe
}

$\approx$ Ta članek raziskuje oblikovanje »globalne« identitete učiteljev Organizacije za gospodarsko sodelovanje in razvoj (OECD) od uvedbe mednarodne raziskave o poučevanju in učenju (TALIS) leta 2008. Kritično preučujemo konceptualne okvire, povezane s TALIS, anketne vprašalnike in statistično podprte lestvice poklicnega odnosa učiteljev na mednarodni ravni. S teoretičnim, na izobraževanju temelječim uokvirjanjem didaktike in kurikularne pedagoške tradicije razpravljamo o konceptualni pristranskosti v konceptualnih okvirih TALIS in sociološko utemeljeni ideji TALIS kot pedagoškem pripomočku, ki se uporablja kot tehnologija za pridobivanje simbolne moči za oblikovanje učiteljev prihodnosti. Metodološko se opiramo na analizo dokumentov, preučujemo temeljne dokumente TALIS 2008, 2013 in 2018, da bi poudarili ideološko pogojeno konstrukcijo določenega modela učinkovitih učiteljev, in se sklicujemo na povezana tehnična poročila TALIS, da bi preučili vprašanja veljavnosti lestvic, ki so metodološko in statistično pogojena, da bi povečali robustnost rezultatov. $\mathrm{V}$ članku so opredeljene pristranskosti v OECD-jevi konstrukciji »globalne« identitete učitelja, ki se odražajo v konceptualnih okvirih in anketnih vprašanjih TALIS, ter so statistično utemeljene s povezanimi lestvicami.

Ključne besede: kurikularna teorija, didaktika, globalna identiteta učitelja, pedagoški pripomoček, TALIS 


\section{Introduction}

The present article investigates how a 'global' teacher identity has been under construction by the Organisation for Economic Cooperation and Development (OECD) since the introduction of the Teaching and Learning International Survey (TALIS) in 2008. This 'global' teacher identity is constructed and promoted externally from teachers' experience, hence the conceptual and methodological construction of a 'global' teacher identity in the title. In order to demonstrate how this has occurred, the article critically examines the OECD's TALIS-related conceptual frameworks, survey questionnaires and statistically driven scales of teachers' professional attitudes internationally. The article's contribution pertains to the construction of a 'global' teacher identity that stems, in turn, from conceptual bias in the structuring of the conceptual frameworks and survey questionnaires, as well as validity limitations related to the methodological construction of TALIS 2008, 2013 and 2018 scales.

The construction and promotion of a 'global' teacher identity through the OECD is no different from other OECD work in education, most notably through the Programme for International Student Assessment (PISA), in that PISA contributes to the shift towards a universally applicable curriculum based on key competences that has affected governance and policies of national education systems (Grek, 2009). In this way, TALIS serves as a pedagogic device that is applied and used as a technology to gain symbolic control over making the teachers of 'tomorrow' (Robertson \& Sorensen, 2018). As a result, TALIS offers a 'desirable' alternative regarding what teachers need to be and do, constructed at a supra-national level and intended as a solution to perceived or assumed problems with teacher quality at the national level. However, such construction of a 'global' teacher identity is not without problems. We turn to the education-based theoretical framing of didaktik and curriculum pedagogical traditions (Hopmann, 2007) to discuss conceptual bias in TALIS conceptual frameworks and survey questionnaires. In this regard, the main goal of the present article is to examine the conceptual and methodological approaches that TALIS uses to construct the 'global' teacher identity it promotes. This is done by shedding light on the theoretical and empirical sources on which TALIS relies, as well as other views of teachers that it ignores.

The article is structured as follows: the next section provides a succinct literature review, followed by theoretical framing, and then methodological considerations and data sources. Next, results are presented, followed by discussion, conclusions and implications. 


\section{Global teacher identities}

Teachers constantly construct and reconstruct their identities amid various forces and interactions in the social and cultural contexts within which schools and communities exist. These constructions and identities are determined by various factors, such as teachers' perceived competence, fulfilment of psychological needs, commitment and self-esteem (Canrinus et al., 2011; Granjo et al., 2020). This section reviews relevant literature on the local and global factors and influences that shape and drive teacher identities in cross-national settings, as well as recent literature addressing TALIS-related topics.

Since the 1960 s, the world has seen a steady stream of studies and surveys on what teachers do and how they perceive themselves in different contexts. Along with the increasing connectivity, this has led to the creation of classrooms that are immersed in policy scenarios cutting across geographic and ideological boundaries. As a result, expectations of teachers have dramatically changed from mere disseminators of knowledge to enabling students to thrive in an ever-changing, multipolar, multicultural world. Spurred by international organisations such as the OECD, frameworks of global competence have come to the fore (e.g., Tichnor-Wagner et al., 2019). Among other topics, these frameworks include knowledge of global issues, empathy towards multiple perspectives, intercultural communication and collaboration as attributes of teachers in the twenty-first century. Cross-national surveys such as the Teacher Education and Development Study in Mathematics (TEDS-M) and TALIS are a significant manifestation of how global actors and processes influence teachers' perceptions of self in the delivery chain of educational services in different contexts. By way of illustration, analyses of TALIS documentation and the discourse therein have shown that the OECD's TALIS "uses a discourse of fear to market teacher quality in light of global changes, implicitly framing teachers as 'bad teachers"' (Berkovich \& Benoliel, 2020a, p. 496) and that TALIS discourse on teacher professionalism is individualist and anti-collectivist in its orientation (Berkovich \& Benoliel, 2020b).

Studies on TEDS-M (e.g., Blömeke et al., 2013) have revealed a complicated relationship between teachers' content and pedagogical knowledge in mathematics, suggesting how this, in turn, leads to peculiar 'identities' that teachers assume in their respective contexts. Other studies emphasise emotions, ideology and culture as the dominant factors driving teacher identities in such a way that teachers find themselves at the receiving end of policy construction and implementation (e.g., Halai \& Durrani, 2018; Wermke \& Salokangas, 2021). Although ideology and culture may be more local forces that shape teacher 
identities, studies also suggest the existence of 'neoliberal' tendencies in school systems, whereby teachers assume 'entrepreneurial' identities and are ready to adopt teaching practices suitable for promising careers in the education system and tuition industry (Gupta, 2019).

Our review suggests that teacher identity is iterative, as teachers continuously shape and reshape their role and place in their professional contexts. The iterations of identity formation are mediated and influenced by teachers' intercultural capabilities and their positionality. At the same time, their identities are also driven, and quite powerfully so, by actors and processes that have a global stature and presence, such as the OECD through TALIS.

\section{Theoretical framework: Educational and sociological lenses}

In order to better understand TALIS, both as content and as a process, we draw on educational and sociological perspectives. First, the educationbased theoretical framing of didaktik and curriculum pedagogical traditions (Hopmann, 2007) is applied to discuss conceptual bias in TALIS conceptual frameworks and survey questionnaires. Next, we draw on Robertson and Sorensen's (2018) sociological idea of TALIS as a 'pedagogic device' (Bernstein, 200o) that is used by the OECD as a technology to gain symbolic power within the field of making the teachers of tomorrow.

From an education perspective, the traditions of Anglo-American curriculum theory and Continental/Nordic European didaktik theory have dominated education in the Western context (Deng \& Luke, 2008; Hopmann, 2007). Within the curriculum tradition, four main ideologies of academic rationalism, humanism, social reconstruction and social efficiency have been influential (Schiro, 2013; Tahirsylaj, 2017), each promoting specific goals for education. Academic rationalism primarily relies on the transmission of disciplinary knowledge; humanism, sometimes referred to as a learner-centred ideology, prioritises the development of individual learners, who pursue personal development, self-actualisation, innovation and creativity; social reconstruction promotes the use of education for social reform, with an emphasis on sociocultural contexts rather than on the individual needs of learners; and social efficiency supports the preparation of future citizens with the requisite skills, knowledge and capital for economic and social productivity (Deng \& Luke, 2008). Of these four ideologies, social efficiency has been the most dominant in education policy in Anglo-American contexts (Tahirsylaj, 2017), and, as will be demonstrated below, it is the one that dominates the OECD's work in education, including TALIS. 
Continental/Nordic didaktik, on the other hand, focuses on teachers' work in designing teaching and learning directed by the concept of Bildung and by the selection of content that has significance for the present and future of students through didaktik analysis (Deng \& Luke, 2008; Klafki, 2000; Tahirsylaj, 2019). Although the German concept Bildung does not have a direct translation in English, it is often referred to in the sense of 'being educated', while in other cases it is referred to as 'self-formation', 'cultivation', 'self-development' and 'cultural process' (Siljander \& Sutinen, 2012). Didaktik rests on three core elements: Bildung, matter and meaning, and teacher professional autonomy (Hopmann, 2007). From a comparative perspective, curriculum and didaktik traditions differ regarding the role of content/disciplinary knowledge and its primacy in teaching and learning. Under didaktik, the focus is on Bildung and professional teacher autonomy, while the curriculum tradition focuses on instructional methods and the primacy of (often external) assessments and is thus evaluation-intensive (Tahirsylaj et al., 2015; Westbury et al., 2000). The two traditions and ideologies within them also promote varied roles for teachers: under didaktik, teachers enjoy higher professional autonomy, while under the curriculum tradition, teachers are agents of the education system and serve to deliver what is asked of them by the system (Westbury et al., 2000). This comparative position is relevant for the present study in order to identify which concepts TALIS draws on in defining the teacher's role and responsibilities, and in turn, the type of teacher identity it promotes.

Lastly, the sociologically based idea of 'pedagogic device' originates from the work of British sociologist Basil Bernstein (2000). Here we follow Robertson and Sorensen (2018) in using Bernstein's concept of pedagogic device for analysing TALIS as an OECD device. Bernstein defined a pedagogic device as having "[...] internal rules which regulate the pedagogic communication which the device makes possible. Such pedagogic communication acts selectively on the meaning potential. By meaning potential we simply mean the potential discourse that is available to be pedagogised" (Bernstein, 2000, p. 27). Furthermore, Bernstein's pedagogic device is described as "the ensembles of rules or procedures via which knowledge is converted into classroom talk, curricula and online communication" (Singh, 2002, p. 571). Bernstein's work has focused primarily on the national level, and he consequently makes the case for the conversion of knowledge within national boundaries (Robertson \& Sorensen, 2018). With TALIS, however, we have a case of an international organisation such as the OECD applying TALIS as a pedagogic device that aims to convert specific knowledge about teachers across various national contexts. More specifically related to our study, TALIS serves as a pedagogic device with regard to 
what is to be transferred to the national context (the global twenty-first century teacher) and is the transponder itself (TALIS). In Bernstein's terms, the global teacher is "the carried" (or what is relayed) and TALIS is "the carrier" (or relay) (Bernstein, 2000, p. 27). However, TALIS is just one of the many pedagogic devices on which the OECD works; others include PISA and 'Education at a Glance' reports, for example (Robertson \& Sorensen, 2018). TALIS functions as a pedagogic device by learning through comparing, development and competition with other countries; by providing robust international indicators for policy-relevant analyses of teachers and teaching; and through cross-country analyses of countries facing similar challenges. A pedagogic device operates through three inter-related rules: distributive, recontextualising and evaluative (Bernstein, 2000). Distributive rules function as rules and processes to regulate relationships between power, social groups and forms of consciousness and practice, and to distribute different forms of knowledge; recontextualising rules regulate the formation of specific pedagogic discourse; and evaluative rules constitute specific pedagogic practices and function as processes of acquisition (Bernstein, 2000; Robertson \& Sorensen, 2018; Singh, 2002). In discussing results through this sociological lens, we will show how TALIS operates as a pedagogic device through distributive, recontextualising and evaluative rules.

\section{Methodology and data materials}

In order to achieve the primary goal of the study, that is, to show how the OECD's TALIS works to construct a certain type of 'global' teacher identity conceptually and methodologically, we apply document analysis of TALIS-related documentation produced by the OECD. TALIS has grown in its international reach from one wave to another. In 2008, 24 national and sub-national systems participated in the survey; in 2013, the number of participants increased to 38 ; and in 2018, the total was 49 (NCES, n.d.). TALIS collects data primarily from lower secondary education teachers (International Standard Classification of Education (ISCED) Level 2) and school principals of their schools, but participating education systems can also use optional surveys of teachers and school principals in ISCED Level 1 and/or ISCED Level 3 (OECD, 2010). TALIS surveys teachers' and principals' attitudes regarding six main aspects - Learning environment; Appraisal and feedback; Teaching practices and classroom environment; Development and support; School leadership; Self-efficacy and job satisfaction - and aims to address five main policy issues - Attracting teachers to the profession; Developing teachers within the profession; Retaining teachers in the profession; School policies and effectiveness; Quality teachers and 
teaching - which are further operationalised into specific indicators (OECD, 2010). TALIS applies stratified two-stage probability sampling, where schools are first randomly selected, followed by the random selection of teachers within those schools. A total of 200 schools and 20 teachers within each participating school is established as a minimum sample size, meaning that a sample of at least 4,000 teachers participates in the survey from each participating education system (OECD, 2010). As shown in the lists of contributors in any of the TALIS documents, ${ }^{5}$ the OECD engages a large number of national government representatives and policymakers in the development and validation of TALIS assessment frameworks, data collection and analysis, as well as in the production of follow-up synthesis reports.

In order to capture the full breadth of TALIS and any evolution in its construction of a 'global' teacher identity, we review conceptual frameworks, survey questionnaires, technical reports and results reports from all three waves of TALIS administered to date: 2008, 2013 and 2018. In addition, we include the OECD's (2005) report Teachers Matter: Attracting, Developing and Retaining Effective Teachers, a key document that was used in the conceptualisation of TALIS prior to its first administration in 2008. All of the documents qualitatively examined here are in the public domain and are freely accessible online. Due to the abundance of TALIS documentation and to space limitations, we can only present snippets of these documents under the results section below in forms of evidence extracted to support our main claim that TALIS promotes a specific 'global' teacher identity around the idea of 'effective teachers' (OECD, 2005). For example, to show the construction of TALIS complex scale indices, we only present data covering two of these indices - Constructivist Beliefs about Instruction, and Need for Teacher Professional Development in Subject Matter and Pedagogy - to highlight validity issues related to such constructions, which are methodologically and statistically driven to support the narratives presented by the OECD and to lend strength to their arguments by augmenting qualitative reporting with statistically robust results.

\section{Results: The conceptual and methodological construc- tion of global teachers through TALIS}

In this section, we present the findings in two subsections: first, we focus on definitions and conceptions of 'the teacher' and 'the teacher's role and responsibilities' in TALIS conceptual frameworks and how these conceptualisations 
are 'translated' into specific indicators and survey questions; and, second, we present two examples of complex scale indices to show how TALIS's theoretical conceptualisations of 'global' teacher identity are backed up by methodological and statistical constructions.

\section{The conceptual construction of global teachers in TALIS}

Our analyses of TALIS-related documentation show that the OECD's (2005) Teachers Matter report provided the foundation for the TALIS survey regarding the target teacher population. ${ }^{6}$ Therefore, in order to understand and capture the conceptual construction of teachers in TALIS, we had to track down and examine connections between the OECD's Teachers Matter (2005) and the subsequent TALIS reports. The OECD (2005) report was based on an OECD study of teacher policy conducted in the period 2002-2004 involving 25 countries around the world, and it was concerned with policies that contribute to attracting, developing and retaining effective teachers in schools. While the OECD's (2005) Teachers Matter report does not specifically define 'effective teachers', we find that 'effective teachers' was presented as the main goal for the OECD and participating countries that collaborated with the OECD on the study. Furthermore, we find that the notion of 'effective teachers' is a consistent theme in all TALIS surveys, and that it is conceptually elaborated when referring to definitions of teachers and teachers' roles and responsibilities. Table 1 captures the associated definitions in the OECD and TALIS documents of focus.

6 In all of its waves, the TALIS survey expanded the net of target populations to include school leaders (school principals), a population that is not the focus of the present article. 


\section{Table 1}

Conceptualisations of teachers and teachers' roles and responsibilities in the OECD's TALIS

\begin{tabular}{|c|c|c|}
\hline & Definitions of teachers & $\begin{array}{l}\text { Definitions of teachers' roles and } \\
\text { responsibilities }\end{array}$ \\
\hline $\begin{array}{l}\text { OECD's } \\
\text { (2005) } \\
\text { Teachers } \\
\text { Matter } \\
\text { report }\end{array}$ & $\begin{array}{l}\text { The teacher profiles need to } \\
\text { encompass strong subject matter } \\
\text { knowledge, pedagogical skills, the } \\
\text { capacity } \\
\text { to work effectively with a wide } \\
\text { range of students and colleagues, to } \\
\text { contribute to the school and the pro- } \\
\text { fession, and the capacity to continue } \\
\text { developing (OECD, 2005, p. 10). }\end{array}$ & $\begin{array}{l}\text { At the individual student level } \\
\text { - } \quad \text { Initiating and managing learning pro- } \\
\text { cesses. } \\
\text { - } \quad \text { Responding effectively to the learning } \\
\text { needs of individual learners. } \\
\text { - } \quad \text { Integrating formative and summative } \\
\text { assessment. } \\
\text { At the classroom level } \\
\text { - } \quad \text { Teaching in multi-cultural classrooms. } \\
\text { - } \quad \text { New cross-curricular emphases. } \\
\text { - Integrating students with special needs. } \\
\text { At the school level } \\
\text { - } \quad \text { Working and planning in teams. } \\
\text { - Evaluation and systematic improvement } \\
\text { planning. } \\
\text { - ICT use in teaching and administration. } \\
\text { - Management and shared leadership. } \\
\text { At the level of parents and the wider com- } \\
\quad \text { munity } \\
\text { - Providing professional advice to parents. } \\
\text { - Building community partnerships for } \\
\text { learning (OECD, 2005, p. 3). }\end{array}$ \\
\hline TALIS 2008 & $\begin{array}{l}\text { "[...] the formal definition of a } \\
\text { classroom teacher is a person whose } \\
\text { professional activity involves the } \\
\text { planning, organising and conduct- } \\
\text { ing of group activities whereby } \\
\text { students' knowledge, skills and } \\
\text { attitudes develop as stipulated by } \\
\text { educational programmes. In short, it } \\
\text { is one whose main activity is teach- } \\
\text { ing" (OECD, 2010, p. } 56 \text {, referencing } \\
\text { OECD }(2004) \text {. }\end{array}$ & Definition missing \\
\hline TALIS 2013 & $\begin{array}{l}\text { A teacher is defined as a person } \\
\text { whose professional activity involves } \\
\text { the transmission of knowledge, atti- } \\
\text { tudes and skills that are stipulated to } \\
\text { students enrolled in an educational } \\
\text { program. (OECD, 2013, p. 20). }\end{array}$ & $\begin{array}{l}\text { Identical text to OECD (2005) (see Box 2: } \\
\text { Responsibilities of today's teachers in OECD, } \\
\text { 2013, pp. 21-22). }\end{array}$ \\
\hline TALIS 2018 & $\begin{array}{l}\text { Identical to the definition in TALIS } \\
2013 \text { (Ainley \& Carstens, 2018, p. } 73 \text { ). }\end{array}$ & Definition missing \\
\hline
\end{tabular}

Extrapolating from the definitions in Table 1, in the OECD's view, an 'effective teacher' is one who possesses the subject matter knowledge and pedagogical skills to be in the service of students in the classroom, the profession 
and the community, and who engages in lifelong learning for personal professional development in order to ensure student learning. The hypothetical 'effective teacher' is projected internationally as a required teacher profile, presenting their preferred version of 'global' teacher identity and overriding national contexts, while at the same time ensuring that countries buy into what the OECD does towards and through TALIS. In order to ensure consistency in its conceptualisation, the OECD serves as a self-referential source in which future conceptual development is based on prior OECD publications, as shown with the repetitions of the definitions in Table 1 from OECD (2005) to future TALIS reports. The intentional conceptual bias towards OECD-produced knowledge and visions of teachers is also exemplified in policy objectives highlighted in OECD (2005) and policy issues in TALIS 2008, as shown in Table 2.

\section{Table 2}

Policy objectives (PO) in OECD (2005) and policy issues (PI) in TALIS 2008

\begin{tabular}{|c|c|c|}
\hline $\begin{array}{l}\text { OECD's (2005) } \\
\text { Teachers Matter report }\end{array}$ & $\begin{array}{l}\text { PO } 1 \\
\text { PO } 2 \\
\text { PO } 3 \\
\text { PO } 4 \\
\text { PO } 5\end{array}$ & $\begin{array}{l}\text { Making teaching an attractive career choice } \\
\text { Developing teachers' knowledge and skills } \\
\text { Recruiting, selecting and employing teachers } \\
\text { Retaining effective teachers in schools } \\
\text { Developing and implementing teacher policy } \\
\text { (OECD, 2005, p. 7) }\end{array}$ \\
\hline $\begin{array}{l}\text { TALIS } 2008 \\
\text { Technical Report }\end{array}$ & $\begin{array}{l}\text { PI } 1 \\
\text { PI } 2 \\
\text { PI } 3 \\
\text { PI } 4 \\
\text { PI } 5\end{array}$ & $\begin{array}{l}\text { Attracting teachers to the profession } \\
\text { Developing teachers within the profession } \\
\text { Retaining teachers in the profession } \\
\text { School policies and effectiveness } \\
\text { Quality teachers and teaching } \\
\text { (OECD, 2010, p. 26) }\end{array}$ \\
\hline
\end{tabular}

The almost mirror replication of the policy objectives noted in the OECD's (2005) Teachers Matter report in the policy issues in TALIS 2008 indicates the OECD's focus on creating a pipeline of 'effective teachers' to the teaching profession. Only Policy Issue 4, which concerns school leadership, is new in TALIS 2008, due to the inclusion of school leaders as a target population. Furthermore, fifteen indicators were developed to address the five policy issues in TALIS 2008. For example, for Policy Issue 2 on Developing teachers within the profession, three indicators were constructed: 1 . Profile of teachers' education and training; 2. Frequency and distribution of education and training; and 3. Satisfaction and effectiveness of education and training (OECD, 2010, p. 26). Again, it appears to be important to highlight the notion of 'effectiveness'.

Next, data was required to construct the desired indicators. Consequently, specific language had to be used in the teacher survey questionnaires that matched the conceptions of teachers from the OECD's perspective. For 
example, in the TALIS 2013 Teacher Questionnaire, one of the questions under Teacher Professional Development reads as follows: During the last 12 months, did you participate in any of the following professional development activities, and if yes, for how many days did they last? Teachers could respond with Yes or No, and indicate the duration in days if they had participated in: a) Courses/workshops; b) Education conferences or seminars; c) Observation visits to other schools; d) Observation visits to business premises, public organisations, non-governmental organisations; and e) In-service training courses in business premises, public organisations, non-governmental organisations (OECD, n.d., p. 10). This question, as well as others focusing on teacher professional development, are in line with the 'effective teacher' ideology incorporated in TALIS conceptual frameworks. Still, as we will argue next, TALIS surveys adopt a deficit mindset in the view of teachers, who are to be blamed for lacking 'effectiveness' and thus always in 'need' of more professional development. In this sense, TALIS serves as an OECD pedagogic device to identify the problem (teachers are ineffective) and also to construct the solution (lifelong learning through teacher professional development).

\section{The methodological construction of global teachers in TALIS}

Next, we present the methodological and statistical construction of two complex scale indices pertaining to Constructivist Beliefs about Instruction, and Need for Teacher Professional Development in Subject Matter and Pedagogy. Constructivism has prominence in TALIS as a preferred pedagogy (Robertson \& Sorensen, 2018), and a teacher with constructivist beliefs is one who facilitates the student's own inquiry. As shown in the components that the index is constructed from in Table 3, a constructivist teacher is one who teaches less but facilitates students' self-inquiry, and one who holds the belief that curriculum content is less important than thinking and reasoning processes. In the OECD's view, a constructivist teacher is a 'good' and 'effective' teacher. Table 4 shows the reliability and model fit test results for the index in TALIS 2013 for a select ten participating countries. ${ }^{7}$ As indicated in the notes to Table 4 , reliability and good model fit values were acceptable for most countries. However, the index was dropped in TALIS 2018 precisely due to measurement issues, as noted in the TALIS 2018 Technical Report: "Eventually, the TALIS 2018 main survey instruments did not cover 'beliefs' about teaching, given sub-par measurement characteristics in the field trial (and originally in TALIS 2013)" (OECD, 2019, p.

7 Due to word limitation, the ten countries in Table 4 and Table 6 are selected alphabetically for demonstration purposes and do not include all of the countries that participated in TALIS 2013. 
79). This demonstrates that the OECD is bounded by statistical reasoning and believes in the power of statistical measures to accurately 'tell the story'.

\section{Table 3}

Construction of Constructivist Beliefs about Instruction Index

\begin{tabular}{|c|c|c|c|c|c|}
\hline \multicolumn{2}{|c|}{$\begin{array}{l}\text { TALIS 2008: Constructivist Beliefs } \\
\text { about Instruction }\end{array}$} & \multicolumn{2}{|c|}{$\begin{array}{l}\text { TALIS 2013: Constructivist Beliefs } \\
\text { about Instruction }\end{array}$} & \multicolumn{2}{|c|}{$\begin{array}{l}\text { TALIS 2018: Constructivist } \\
\text { Beliefs about Instruction }\end{array}$} \\
\hline Component & $\begin{array}{l}\text { Factor } \\
\text { Loading }\end{array}$ & Component & $\begin{array}{l}\text { Factor } \\
\text { Loading }\end{array}$ & Component & $\begin{array}{l}\text { Factor } \\
\text { Loading }\end{array}$ \\
\hline $\begin{array}{l}\text { My role as a teacher is to } \\
\text { facilitate student's own } \\
\text { inquiry }\end{array}$ & 1.001 & $\begin{array}{l}\text { My role as a teacher is } \\
\text { to facilitate student's } \\
\text { own inquiry }\end{array}$ & .916 & No Index & \\
\hline $\begin{array}{l}\text { Students learn best } \\
\text { by finding solutions to } \\
\text { problems on their own }\end{array}$ & 1.462 & $\begin{array}{l}\text { Students learn best } \\
\text { by finding solutions to } \\
\text { problems on their own }\end{array}$ & 1.383 & & \\
\hline $\begin{array}{l}\text { Students should be } \\
\text { allowed to think of solu- } \\
\text { tions to practical prob- } \\
\text { lems themselves before } \\
\text { the teacher shows them } \\
\text { how they are solved }\end{array}$ & 1.427 & $\begin{array}{l}\text { Students should be } \\
\text { allowed to think of } \\
\text { solutions to practical } \\
\text { problems themselves } \\
\text { before the teacher } \\
\text { shows them how they } \\
\text { are solved }\end{array}$ & 1.226 & & \\
\hline $\begin{array}{l}\text { Thinking and reason- } \\
\text { ing processes are more } \\
\text { important than specific } \\
\text { curriculum content }\end{array}$ & 1.000 & $\begin{array}{l}\text { Thinking and reason- } \\
\text { ing processes are more } \\
\text { important than specific } \\
\text { curriculum content }\end{array}$ & 1.000 & & \\
\hline
\end{tabular}

Note. Adapted from OECD, 2014a, Tables 10.62 \& 10.66; OECD, 2010, Tables 11.74 \& 11.80.

\section{Table 4}

TALIS 2013 Reliability and Model Fit for Constructivist Beliefs about Instruction Index

\begin{tabular}{lccccc}
\hline Countries & Coefficient Alpha & CFI & TLI & RMSEA & SRMR \\
\hline Australia & .705 & .998 & .994 & .018 & .009 \\
Brazil & .685 & .957 & .871 & .054 & .029 \\
Bulgaria & .621 & .992 & .976 & .030 & .015 \\
Denmark & .669 & .998 & .994 & .018 & .009 \\
Estonia & .647 & .999 & .998 & .010 & .007 \\
Iceland & .778 & .960 & .880 & .122 & .027 \\
Italy & .659 & .953 & .859 & .089 & .031 \\
Korea & .843 & .996 & .987 & .040 & .010 \\
Mexico & .681 & .999 & .997 & .014 & .009 \\
Norway & .541 & .992 & .975 & .022 & .013 \\
\hline
\end{tabular}

Note. Sample of countries that participated in all three rounds of TALIS $(2008,2013,2018)$ included. ISCED 2 results provided. Model fit indices based on confirmatory factor analysis and include Compara- 
tive Fit Index (CFI), Tucker Lewis Index (TLI), Root Mean Square of Error Approximation (RMSEA), and Standardized Root Mean Square Residual (SRMR). Reliability is considered acceptable if Coefficient Alpha is $\geq .70$. Good model fit is indicated by CFI $\geq .90$, TLI $\geq .95$, RMSEA $<.08$, and SRMS $<.08$. Adapted from Hooper et al., 2008; OECD, 2014a, Tables 10.63 \& 10.64; OECD, 2010, Tables 11.77 \& 11.84; Taber, 2018.

Tables 5 and 6 show the construction and the statistical measures of the index on Need for Professional Development in Subject Matter and Pedagogy, which was computed in TALIS 2013 and 2018 (not in TALIS 2008). Here we again observe the 'deficit mindset', as the index 'constructs' the 'need' for professional development. Lacking the requisite attributes, the onus seems to be placed on teachers to gain skills, with little regard for systemic and structural deficits that may hamper teachers' ability to participate, including adequate resources and opportunities. The index reflects the conceptual constructions of the need for professional development as noted in conceptual frameworks and teacher survey questionnaires, but here it is given the added value of the 'statistical power' of factor loadings, reliability and good model fit test values. Furthermore, the index itself does not communicate much information of use (other than a deficit), and the general statements/components that make up the index are so broad that most teachers might be expected to respond that some level of professional development is needed. Indeed, the general statements/ components themselves do little to identify which areas of professional development should be invested in to meet teacher needs. Table 6 shows reliability and model fit test results of the index in 2013.

\section{Table 5}

Construction of Need for Professional Development in Subject Matter and Pedagogy Index

\begin{tabular}{|c|c|c|c|c|c|}
\hline \multicolumn{2}{|c|}{$\begin{array}{l}2008 \text { TALIS: Need for Profes- } \\
\text { sional Development in Sub- } \\
\text { ject Matter and Pedagogy }\end{array}$} & \multicolumn{2}{|c|}{$\begin{array}{l}2013 \text { TALIS: Need for Professional } \\
\text { Development in Subject Matter } \\
\text { and Pedagogy }\end{array}$} & \multicolumn{2}{|c|}{$\begin{array}{l}2018 \text { TALIS: Need for Profes- } \\
\text { sional Development in Subject } \\
\text { Matter and Pedagogy }\end{array}$} \\
\hline Component & $\begin{array}{l}\text { Factor } \\
\text { Loading }\end{array}$ & Component & $\begin{array}{l}\text { Factor } \\
\text { Loading }\end{array}$ & Component & $\begin{array}{l}\text { Factor } \\
\text { Loading }\end{array}$ \\
\hline \multirow[t]{5}{*}{ No Index } & & $\begin{array}{l}\text { Knowledge and under- } \\
\text { standing of my subject } \\
\text { field(s) }\end{array}$ & 1.000 & $\begin{array}{l}\text { Knowledge and } \\
\text { understanding of my } \\
\text { subject field(s) }\end{array}$ & .651 \\
\hline & & $\begin{array}{l}\text { Pedagogical compe- } \\
\text { tencies in teaching my } \\
\text { subject field(s) }\end{array}$ & 1.050 & $\begin{array}{l}\text { Pedagogical compe- } \\
\text { tencies in teaching } \\
\text { my subject field(s) }\end{array}$ & .684 \\
\hline & & $\begin{array}{l}\text { Knowledge of the cur- } \\
\text { riculum }\end{array}$ & .929 & $\begin{array}{l}\text { Knowledge of the } \\
\text { curriculum }\end{array}$ & .707 \\
\hline & & $\begin{array}{l}\text { Student evaluation and } \\
\text { assessment practice }\end{array}$ & .933 & $\begin{array}{l}\text { Student assessment } \\
\text { practice }\end{array}$ & .688 \\
\hline & & $\begin{array}{l}\text { Student behavior and } \\
\text { classroom manage- } \\
\text { ment }\end{array}$ & .823 & $\begin{array}{l}\text { Student behavior } \\
\text { and classroom man- } \\
\text { agement }\end{array}$ & .622 \\
\hline
\end{tabular}


Note. Adapted from OECD, 2019, Tables 11.41 \& 11.51; OECD,2014a, Tables 10.81 \& 10.85.

\section{Table 6}

TALIS 2013 Reliability and Model Fit for Need for Professional Development in Subject Matter and Pedagogy Index

\begin{tabular}{lccccc}
\hline Countries & Coefficient Alpha & CFI & TLI & RMSEA & SRMR \\
\hline Australia & .849 & .972 & .930 & .077 & .024 \\
Brazil & .850 & .987 & .967 & .039 & .020 \\
Bulgaria & .897 & .935 & .837 & .149 & .039 \\
Denmark & .803 & .957 & .892 & .101 & .030 \\
Estonia & .837 & .942 & .854 & .138 & .035 \\
Iceland & .788 & .933 & .832 & .138 & .058 \\
Italy & .864 & .981 & .953 & .076 & .020 \\
Korea & .910 & .981 & .953 & .076 & .020 \\
Mexico & .853 & .975 & .937 & .096 & .027 \\
Norway & .787 & .995 & .988 & .025 & .012 \\
\hline
\end{tabular}

Note. Sample of countries that participated in all three rounds of TALIS $(2008,2013,2018)$ included. ISCED 2 results provided. Model fit indices based on confirmatory factor analysis and include Comparative Fit Index (CFI), Tucker Lewis Index (TLI), Root Mean Square of Error Approximation (RMSEA), and Standardized Root Mean Square Residual (SRMR). Reliability is considered acceptable if Coefficient Alpha is $\geq .70$. Good model fit is indicated by $C F I \geq .90, T L I \geq .95$, RMSEA $<.08$, and SRMS $<.08$.

Adapted from Hooper et al., 2008; OECD, 2019, Tables 11.42 \& 11.44; OECD, 2014a, Tables 10.81 \& 10.85; Taber, 2018.

\section{Discussion: Educational and sociological perspectives on TALIS construction of 'global' teachers}

The results reveal the conceptual bias of TALIS towards curriculum ideologies, primarily social efficiency and learner-centred ideologies, as exemplified in the notions dominating the definitions of teachers and teachers' roles, as well as those constituting components of Constructivist Beliefs about Instruction, and Need for Professional Development in Subject Matter and Pedagogy. Specifically, the definitions and construction of indices are dominated by language focusing on learning and assessment, language dubbed as 'learnification' (Biesta, 2010), which pushes content and teaching into the margins, stripping teachers of any substantial decision making in their professional activity. For example, the fourth component of Constructivist Beliefs about Instruction index reads "Thinking and reasoning processes are more important than specific 
curriculum content" (see entry in Table 3 above), thus implying a diminutive role of content in teaching and learning, which, from the didaktik perspective, is the cornerstone of the educational experience, as it contributes towards students' Bildung and the tight relationship between content and meaning making (Hopmann, 2007; Tahirsylaj, 2019).

Similarly, 'the deficit mindset' observed in the Need for Professional Development in Subject Matter and Pedagogy index is also conceptually aligned with the curriculum tradition, exemplified by the use of the term 'competencies' and 'student assessment' in its components. In particular, the term 'competencies' is closely aligned with the social efficiency ideology (Tahirsylaj \& Wahlström, 2019), while student evaluation and assessment is actively and intensively pursued within the curriculum tradition (Tahirsylaj et al., 2015; Westbury et al., 2000). Two visions of teachers become apparent when examining the TALIS definition of teachers and teachers' roles by focusing on 'effective teachers' through the two educational perspectives. On one hand, the vision of the curriculum tradition, from which TALIS borrows, constructs 'good and effective' teachers as ones who are fully trained to deliver whatever curriculum is promoted by government authorities by staying true and loyal to the given curriculum expectations. On the other hand, as discussed earlier in the theoretical framework section, the vision of the didaktik tradition projects 'good and effective' teachers as ones who unpack the curriculum based on their professional autonomy, not necessarily blindly following authorities' curriculum guidelines, but relying on their professional judgement instead.

Furthermore, the results reveal how the OECD uses TALIS as a pedagogic device to regulate the pedagogic discourse around 'effective' teachers internationally. TALIS serves as a pedagogic device built on specific conceptual and methodological constructions that in turn produce 'valid' knowledge relying on a set of policy issues and indicators to be converted into teacher policies at the national level. The OECD achieves this through the buy-in of national governments and policymakers to TALIS work, and also through the recurring administration of TALIS every five years. Moreover, the OECD's technical and financial prowess enables the collection of large data points from teachers and school leaders in participating countries, which are then converted into 'robust' statistically driven indices and 'evidence-based' indicators and policies for national governments to adopt. In this sense, the sociological position we adopt here describes how TALIS operates as a process and as a pedagogic device to construct a 'global' teacher identity construed from the curriculum's social efficiency-based idea of 'teacher effectiveness' for developing certain skills and competencies among students. Since the actual decision-making power in education rests with national 
governments, the OECD's TALIS as a pedagogic device is aimed at gaining and maintaining symbolic power over the making of twenty-first century teachers (Robertson \& Sorensen, 2018). In order to achieve this, and in light of Bernstein's notion of a pedagogic device operating through a set of distributive, recontextualising and evaluative rules, the OECD's TALIS functions as a distributive rule through the conceptual construction of indicators and policy issues (see Table 2 above) for attracting, developing and retaining 'good and effective' teachers. Next, TALIS as a pedagogic device operates through the recontextualising rule by regulating the formation of specific pedagogic discourse on 'effective teachers', which is executed through numerous publications prior to and following each administration of the TALIS survey. Through recontextualisation, the indicators and policy issues are transmitted to national contexts. Lastly, through evaluative rules, TALIS as a pedagogic device ensures the acquisition of indicators based on the specific pedagogic practices for which TALIS as a survey instrument collects data. The acquisition of indicators is particularly enforced through the process of statistically developing complex scale indices.

\section{Conclusions, implications and further research}

Surprisingly, TALIS indices do not produce much variance across countries, as would be expected considering the wide range of national contexts of the countries participating in TALIS surveys. This may be due, in part, to the selection and statistical validation process of index creation. Indices that perform poorly in multiple countries are dropped, and index components are selectively chosen to reflect a broad but normative conceptualisation of an effective teacher. Furthermore, the lack of variance may be explained by the lack of interest in the voices of teachers. The focus is instead on the distribution and recontextualisation of values in relation to the longstanding reform agenda on teacher effectiveness that we refer to as a 'global' teacher identity.

Conceptually, a 'global' teacher identity is constructed by relying on a specific vision of teachers as agents of the system who need to implement whatever authorities put in front of them in the form of curriculum guidelines and school reform initiatives, as discussed under the theoretical framework referring to Westbury et al. (2000). Through its work, TALIS attempts to override national contexts by reaching out directly to teachers internationally, as demonstrated in A Teachers' Guide to TALIS 2013 (OECD, 2014b). TALIS produces 'validity' by the incorporation of education policymakers in the countries and by the use of tremendous financial resources in the production of large statistical power through sample size. The use of reliability and model fit tests 
are additional statistical tools to increase the robustness of scale indices.

The construction of a specific 'global' teacher identity around teacher effectiveness has direct implications for national teacher education policy and indirectly for teachers' professional identity and practices. Specifically, this study has implications for pre-service teacher education and in-service teacher professional development, as it reveals two different visions of how 'good' or 'effective' teachers are construed in the twenty-first century: one rooted in the curriculum tradition towards which TALIS is biased, and the other rooted in the didaktik tradition. Such contrasting visions impact the design of pre-service teacher education programmes and in-service professional development offerings. In turn, these programmes and offerings potentially affect participating teachers' teaching practices in their classroom work. The decision regarding which vision is pursued ultimately determines whether teaching force is viewed as a delivery mechanism of curriculum guidelines (the curriculum vision), or a professional teaching force that translates curriculum guidelines into educational teaching and learning activities based on the unique meetings of a given teacher with specific students in a given context, pursuing Bildung and meaning making (the didaktik vision).

Lastly, different research avenues could be pursued based on the findings and limitations of the present study. For example, we have applied an educational and sociological framework to examine TALIS documentation that limits the perspectives on TALIS reports, while future research could expand the theoretical net towards historical, philosophical or psychological perspectives. Moreover, a more focused comparative analysis could examine select number of TALIS participating countries to compare the 'construction' of teachers through TALIS versus the 'construction' of teachers at the national level. This line of research could be further pursued at the school level by exploring how teachers' view themselves in light of different visions of teachers at the national or transnational level. Similarly, the comparative perspective could be pursued sociologically at the national level through an exploration of 'pedagogic devices' in use within or across national contexts.

\section{References}

Ainley, J., \& Carstens, R. (2018). Teaching and learning international survey (TALIS) 2018 conceptual framework. OECD Education Working Papers No. 187, https://dx.doi.org/10.1787/799337c2-en Berkovich, I., \& Benoliel, P. (2020a). Marketing teacher quality: Critical discourse analysis of OECD documents on effective teaching and TALIS. Critical Studies in Education, 61(4), 496-511. https://doi. org/10.1080/17508487.2018.1521338 
Berkovich, I., \& Benoliel, P. (2020a). The educational aims of the OECD in its TALIS insight and lesson reports: Exploring societal orientations. Critical Studies in Education, 61(2), 166-179. https:// doi.org/10.108o/17508487.2017.1370428

Bernstein, B. (2000). Pedagogy, symbolic control, and identity: Theory, research, critique. Rowman and Littlefield.

Biesta, G. J. J. (2010). Good education in an age of measurement: Ethics, politics, democracy. Paradigm Publishers.

Blömeke, S., Suhl, U., \& Döhrmann, M. (2013). Assessing strengths and weaknesses of teacher knowledge in Asia, Eastern Europe, and Western countries: Differential item functioning in Teds-M. International Journal of Science and Mathematics Education, 11(4), 795-817. https://doi.org/10.1007/ s10763-013-9413-o

Canrinus, E. T., Helms-Lorenz, M., Beijaard, D., Buitink, J., \& Hofman, A. (2011). Profiling teachers' sense of professional identity. Educational Studies, 37(5), 593-608. https://doi.org/10.1080/03055698. 2010.539857

Deng, Z., \& Luke, A. (2008). Subject matter: Defining and theorizing school subjects. In F. M.

Connelly, M. F. He, \& J. Phillion (Eds.), The sage handbook of curriculum and instruction (pp. 66-87). Sage.

Granjo, M., Castro Silva, J., \& Peixoto, F. (2020). Teacher identity: Can ethical orientation be related to perceived competence, psychological needs satisfaction, commitment and global self-esteem? European Journal of Teacher Education, 1-22. https://doi.org/10.108o/02619768.2020.1748004 Grek, S. (2009). Governing by numbers: The PISA 'effect' in Europe. Journal of Education Policy, 24(1), 23-37. https://doi.org/10.1080/02680930802412669

Gupta, A. (2019). Teacher-entrepreneurialism: A case of teacher identity formation in neoliberalizing education space in contemporary India. Critical Studies in Education, 1-17. https://doi.org/10.1080/17 508487.2019.1708765

Halai, A., \& Durrani, N. (2018). Teachers as agents of peace? Exploring teacher agency in social cohesion in Pakistan. Compare, 48(4), 535-552. https://doi.org/10.1080/03057925.2017.1322491 Hooper, D., Coughlan, J., \& Mullen, M. R. (2008). Equation modelling: Guidelines for determining model fit. Electronic Journal of Business Research Methods, 6(1), 53-6o.

Hopmann, S. (2007). Restrained teaching: The common core of Didaktik. European Educational Research Journal, 6(2), 109-124.

Klafki, W. (2000). Didaktik analysis as the core preparation of instruction. In I. Westbury, S. Hopmann, \& K. Riquarts (Eds.), Teaching as a reflective practice: The German Didaktik tradition (pp. 139-159). Lawrence Erlbaum Associates.

National Center for Education Statistics (NCES). (n.d.). Teaching and Learning International Survey (TALIS). https://nces.ed.gov/surveys/talis/countries.asp OECD. (2019). TALIS 2018 technical report. OECD. https://www.oecd.org/education/talis/ TALIS_2018_Technical_Report.pdf OECD. (2014a). TALIS 2013 technical report. OECD. http://www.oecd.org/education/school/TALIS- 
technical-report-2013.pdf

OECD. (2014b). A teachers' guide to TALIS 2013. OECD. http://www.oecd.org/edu/school/

TALISTeachers-Guide.pdf

OECD. (2013). The TALIS 2013 conceptual framework. OECD.

OECD. (2010). TALIS 2008 technical report. OECD. http://www.oecd.org/education/school/TALIS-

2008-Technical-Report.pdf

OECD. (2005). Teachers matter: Attracting, developing and retaining effective teachers. OECD.

OECD. (2004). OECD Handbook for internationally comparative education statistics: Concepts, standards, definitions, and classifications. OECD.

OECD. (n.d.) TALIS 2013 teacher questionnaire. OECD. http://www.oecd.org/education/school/

TALIS-2013-Teacher-questionnaire.pdf

Robertson, S. L., \& Sorensen, T. (2018). Global transformations of the state, governance and teachers' labour: Putting Bernstein's conceptual grammar to work. European Educational Research Journal, 17(4), 470-488. https://doi.org/10.1177/1474904117724573

Schiro, M. S. (2013). Curriculum theory: Conflicting visions and enduring concerns. Sage.

Siljander, P., \& Sutinen, A. (2012). Introduction. In P. Siljander, A. Kivelä, \& A. Sutinen (Eds.),

Theories of Bildung and growth: Connections and controversies between continental educational thinking and American pragmatism (pp. 1-18). Sense Publishers.

Singh, P. (2002). Pedagogising knowledge: Bernstein's theory of the pedagogic device. British Journal of Sociology of Education, 23(4), 571-582.

Taber, K. S. (2018). The use of Cronbach's alpha when developing and reporting research instruments in science education. Research in Science Education, 48(6), 1273-1296.

Tahirsylaj, A. (2019). Revisiting 'curriculum crisis' dialogue: In search of an antidote. Nordic Journal of Studies in Education Policy, 5(3), 180-190.

Tahirsylaj, A., \& Wahlström, N. (2019). Role of transnational and national education policies in realisation of critical thinking: the cases of Sweden and Kosovo. The Curriculum Journal, $30(4)$, 484-503. https://doi.org/10.108o/09585176.2019.1615523

Tahirsylaj, A. (2017). Curriculum field in the making: Influences that led to social efficiency as dominant curriculum ideology in progressive era in the U.S. European Journal of Curriculum Studies, 4(1), 618-628.

Tahirsylaj, A., Niebert, K., \& Duschl, R. (2015). Curriculum and didaktik in $21^{\text {st }}$ century: Still divergent or converging? European Journal of Curriculum Studies, 2(2), 262-281.

Tichnor-Wagner, A., Parkhouse, H., Glazier, J., \& Cain, J. M. (2019). Becoming a globally competent teacher. ASCD.

Wermke, W., \& Salokangas, M. (2021). The autonomy paradox. Teachers'self-governance across Europe. Springer. 


\section{Biographical note}

Armend Tahirsylaj, PhD, is Associate Professor of Education at the Department of Teacher Education, Norwegian University of Science and Technology (NTNU), Norway. His teaching and research focus on curriculum theory, Didaktik/Bildung, education policy, teacher education, international large-scale assessments, and international comparative education from AngloAmerican and Continental/Nordic Europe angles.

William C. Smith, $\mathrm{PhD}$, is Senior Lecturer in Education and International Development and Academic Lead for the Data for Children Collaborative with UNICEF at the University of Edinburgh. His research focuses on education access and barriers to education for the most marginalized, and issues around testing, teachers, and accountability. He previously worked at UNESCO's Global Education Monitoring Report and as a TJA Fellow with the OECD.

Gulab Khan, PhD, is Assistant Professor at Syed Ahsan Ali and Syed Maratib Ali School of Education, Lahore University of Management Sciences, Pakistan. His research interests lie at the intersection of education policy and practice with a focus on school improvement, educational change, teacher quality and status, and teacher evaluation.

Wieland Wermke, PhD, is Associate Professor in Special Education at Stockholm University, Sweden. His research interest is on comparative education methodology, and educational professionals in the tension field between policy and practice. His latest publication is together with Maija Salokangas: "Autonomy Paradox. Teachers' perceptions on self-governance across Europe" (2021 at Springer). 